\title{
EFFECTS OF REAPING TIME ON VOLATILE COMPONENTS OF NATURAL PHLOMIS RIGIDA LABILL. AND PHLOMIS MONOCEPHALA P.H.DAVIS IN TURKEY
}

\author{
SARIKAYA, A. G. ${ }^{1 *}-$ FAKIR, H. $^{2}$ \\ ${ }^{1}$ Bursa Technical University, Faculty of Forestry, Bursa, Turkey \\ ${ }^{2}$ Isparta University of Applied Sciences, Faculty of Forestry, Isparta, Turkey \\ (phone: +90-533-196 79 86) \\ *Corresponding author \\ e-mail: aysegulsarikaya86@gmail.com \\ (Received $3^{\text {rd }}$ Nov 2018; accepted $16^{\text {th }}$ Jan 2019)
}

\begin{abstract}
In this study, conducted between 2015 and 2017, 49 different volatile components were identified from Phlomis rigida Labill that was reaped from Gölcük highland located on Konya Seydişehir-Bozkır road and Phlomis monocephala P.H.Davis that was reaped from Mersin Silifke Bahçederesi Village in Turkey at three different periods (pre-flowering, flowering and post-flowering) through gas chromatography mass spectroscopy (GC-MS) after solid phase micro extraction (SPME). The main components of Phlomis rigida were found to be (E)-2-Hexenal (9.21\%), $\beta$-Caryophyllene (60.23\%) and Germacrene D $(9.76 \%)$. The main components of Phlomis monocephala were found to be $\alpha$-Pinene (15.59\%), (E)- $\beta$-Farnesene (17.69\%) and Germacrene D (18.92\%). It was concluded that reaping $P$. rigida and $P$. monocephala species during the flowering period was important for the yield of volatile components.
\end{abstract}

Keywords: Phlomis, GC-MS, Germacrene D, $\alpha$-Pinene, Turkey

\section{Introduction}

Turkey has a rich diversity of plant and animal species thanks to its geographical location, geological, geomorphological and climatic features. Turkey is a bridge between Asia and Europe; therefore, it has three different flora zones. For that reason, several species of Asian and European origin are distributed in Turkey (Durmuşkahya, 2005). Located at the intersection of three phytogeographical zones, Turkey has a high species endemism due to the high species richness and endemism by ecological and phytogeographical differentiation as a result of several factors such as its function as a bridge between the floras of South Europe and Southeast Asia, and since Anatolia is the hub of origin and differentiation for several genera and sections (Tan, 1992). Flora of Turkey has around 11,466 plant taxa, whereas European continent has around 12,000 plant taxa. Almost 3649 plant taxa out of those that are naturally distributed in Turkey are endemic (Güner et al., 2012). Hundreds of plant species naturally distributed in Turkey including the endemic species have a very high medical and aromatic value (Baydar, 2009).

Volatile oils have been used as therapeutic medicine since ancient times (Kubecka, 1973). Volatile oils are volatile lipoid mixtures with strong smell that are derived from plants or herbal drugs through water or steam distillation, and that are liquid under normal conditions but sometimes can be frozen (Tanker and Tanker, 1990). In particular, those medical and aromatic plants with a rich content of volatile oil are especially important. Volatile oils (extracts, etheric oils) and their aromatic extracts are 
commonly used in the fragrance and flavour industries as the source for perfumes, food additives, cleaning substances, cosmetic and medicine preparations, aroma-chemicals or initial material for synthesis of nature-identical and semi-synthetic beneficial aroma chemicals. Particularly, there has been a tremendous increase in the demand for volatile oils to be used in aromatherapy practices that have become popular in recent years (Weiss, 1997).

Across the world, Lamiaceae family that can grow nearly everywhere regardless of habitat type and elevation is one of the largest families considering the number of its members (Watson and Dallwitz, 1978). Its widest distribution area is located in the Mediterranean Basin, while the taxa in this family are mainly the open field plants except some of the genera growing in the tropical rain forests (Watson and Dallwitz, 1978; Morgaris et al., 1982; Davis, 1988). With 200 genera and around 3200 species, Lamiaceae family has 45 genera and 546 species in Turkey (Davis, 1982; Baytop, 1997).

Phlomis that is one of the genera of Lamiaceae family has around 100 species around the world. It is represented by a total of 52 taxa including 39 taxa and 13 hybrids in The checklist of the Flora of Turkey (Güner et al., 2012). Its appetising leaves and flowers are used as anti-allergic, diuretic, anti-diarrheal, gas relieving, stomach relieving, painkilling, antidiabetic herbal tea and tonic. Furthermore, it s known to be commonly used by people for respiratory diseases and haemorrhoid (Harput et al., 2006).

In the last decade, there have been important developments with respect to the discovery of pharmacological mechanisms of Phlomis species and associated different components. The phytochemical studies on Phlomis showed that the species contained iridoid, flavonoid, phenylpropanoid, phenylethanoid, lignan, neolignan, diterpenoid, alkoloid and volatile oils (Kamel et al., 2000; Zhang and Wan, 2008).

Phlomis rigida Labill. is a perennial herbaceous plant that can grow as high as 125 $\mathrm{cm}$ with glandular hairs. Its leaves are large, oblong, elliptic or cuneate and have a size of 5-30 x 2-10 cm with pale greenish colour and tomentose hairs. It is verticillate, has 58- 18 flowers, numerous bracteoles, subulate $20-25 \mathrm{~mm}$, calyx is $15-23 \mathrm{~mm}$ and dense hispid stellate-tomentose hairs, corolla is pink-purple. On the other hand, Phlomis monocephala P.H.Davis is a bush species that can grow as high as $150 \mathrm{~cm}$ with glandular hairs. Its leaves are ovate-lanceolate or ovate-oblong, cuneate or truncate, under leaf surface is yellowish and densely stellate-tomentose, upper hairs are greenish stellate-tomentose, and its size is around 2-6,5 x 1-3,5 cm. It is verticillate with 6-12 flowers, bracteole lanceolate is $5-8 \times 1,5-2 \mathrm{~mm}$ long, calyx is $10-14 \mathrm{~mm}$ and has stellatetomentose-lanate hairs, corolla is yellow (Davis, 1982). The purpose of this study was to identify the impact of different reaping times of Phlomis rigida and $P$. monocephala taxa on volatile oil components and determine the appropriate reaping time.

\section{Materials and Methods}

This study was conducted between 2015 and 2017. The research materials that were Phlomis rigida Labill. and Phlomis monocephala P.H.Davis were reaped from Gölcük Highland located on Konya Seydişehir-Bozkır road at an elevation of $1732 \mathrm{~m}$ $\left(37^{\circ} 13^{\prime} 21^{\prime \prime} \mathrm{N}, 32^{\circ} 00^{\prime} 28^{\prime \prime} \mathrm{E}\right)$ and Mersin Silifke Bahçederesi Village in Turkey at an elevation of $527 \mathrm{~m}\left(36^{\circ} 21^{\prime} 17^{\prime \prime} \mathrm{N}, 33^{\circ} 48^{\prime} 28^{\prime \prime} \mathrm{E}\right)$, respectively (Figure 1). The samples were collected from the pre-determined sampling plots in 3 different periods, which were pre-flowering, flowering and post-flowering periods. 


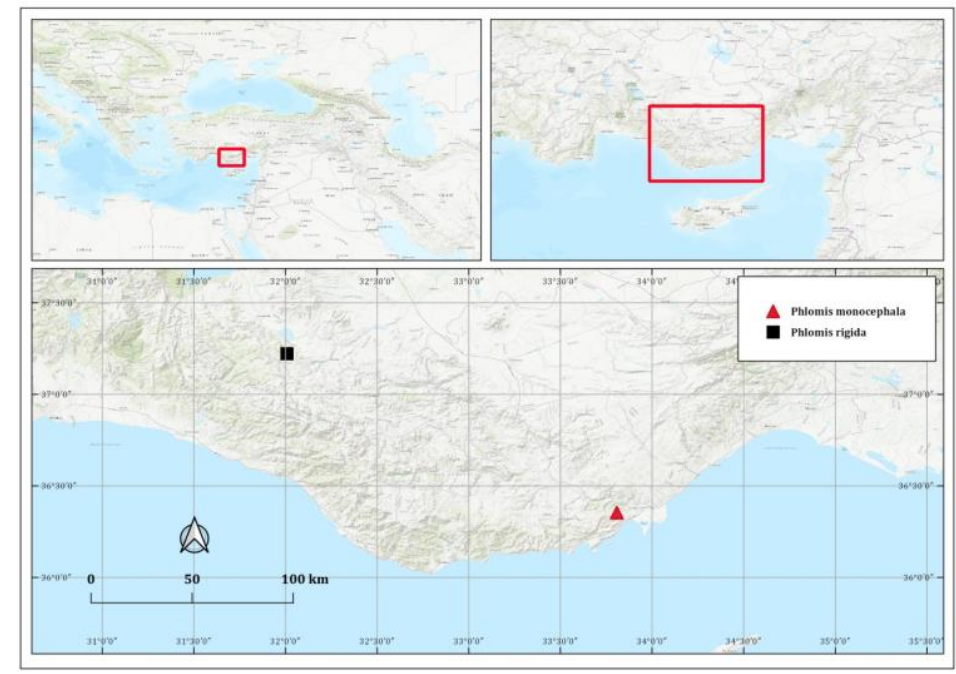

Figure 1. Stands of collecting samples

The leaf and flower samples of Phlomis rigida and P. monocephala collected from the sampling plots were placed in paper packages and transported to the laboratory without delay and avoiding their exposure to sunlight by private car in same day.

Flower and leaf samples were dried in room temperature $\left(25^{\circ} \mathrm{C}\right)$ and processed for solid phase microextraction (SPME). Samples were put into $10 \mathrm{~mL}$ vials from each after incubation at $60^{\circ} \mathrm{C}$ during $30 \mathrm{~min}$. Then, GC-MS (Shimadzu 2010 Plus) process were applied at a temperature of $250^{\circ} \mathrm{C}$ for desorption $(5 \mathrm{~min})$ of the adsorbed volatile compounds for analysis. Constituents were identified by using libraries.

\section{Results}

The volatile components in the leaves and flowers of Phlomis rigida Labill. and $P$. monocephala P.H.Davis collected from the sampling plots were identified through gas chromatography mass spectroscopy (GC-MS) after solid phase micro extraction (SPME).

SPME analysis revealed 49 different volatile components Phlomis rigida and $P$. monocephala. The results of these samples are presented in Table 1.

(E)-2-Hexenal, $\beta$-Caryophyllene and Germacrene D were found to be the main components in Phlomis rigida. The rates in the pre-flowering period were as follows: (E)-2-Hexenal (8.23\%), $\beta$-Caryophyllene $(46.65 \%)$ and Germacrene D $(8.74 \%)$; while the rates during the flowering period were as follows: (E)-2-Hexenal (9.21\%), $\beta$ Caryophyllene (60.23\%) and Germacrene D $(9.76 \%)$; and the rates in the post-flowering period were as follows: (E)-2-Hexenal (8.85\%), $\beta$-Caryophyllene $(56.01 \%)$ and Germacrene D (9.29\%) (Table 1).

$\alpha$-Pinene, (E)- $\beta$-Farnesene and Germacrene $\mathrm{D}$ were found to be the main components of Phlomis monocephala. The rates in the pre-flowering period were as follows: $\alpha-$ Pinene (14.90\%), (E)- $\beta$-Farnesene $(16.47 \%)$ and Germacrene D $(17.78 \%)$; while the rates during the flowering period were as follows: $\alpha$-Pinene $(15.59 \%),(\mathrm{E})-\beta$-Farnesene $(17.69 \%)$ and Germacrene D (18.92\%); and the rates in the post-flowering period were as follows: $\alpha$-Pinene (14.63\%), (E)- $\beta$-Farnesene $(15.69 \%)$ and Germacrene D $(16.16 \%)$ (Table 1). 
Table 1. Volatile components of Phlomis rigida Labill. and P. monocephala P.H.Davis in different vegetation periods

\begin{tabular}{|c|c|c|c|c|c|c|c|c|}
\hline & & & \multicolumn{3}{|c|}{$P$. rigida } & \multicolumn{3}{|c|}{ P. monocephala } \\
\hline & $\mathbf{R t}$ & Components & $\begin{array}{c}\text { Pre } \\
\text { flowering }\end{array}$ & Flowering & $\begin{array}{c}\text { Post } \\
\text { flowering }\end{array}$ & $\begin{array}{c}\text { Pre } \\
\text { flowering }\end{array}$ & Flowering & $\begin{array}{c}\text { Post } \\
\text { flowering }\end{array}$ \\
\hline 1. & 1.403 & Dimethyl sulphide & 1.04 & 0.44 & 0.67 & - & - & - \\
\hline 2. & 1.440 & 2-Methyl-propenal & 0.35 & 0.18 & 0.29 & - & - & - \\
\hline 3. & 1.517 & 3-Methyl-2-butanone & 0.30 & 0.10 & 0.19 & - & - & - \\
\hline 4. & 1.887 & Crotonaldehyde & 0.37 & 0.23 & 0.39 & 0.77 & 0.80 & 0.58 \\
\hline 5. & 1.929 & 3-Methylbutanal & 1.16 & 0.21 & 0.46 & 0.37 & 0.10 & 0.84 \\
\hline 6. & 2.009 & 2-Methylbutanal & 1.08 & 0.33 & 0.85 & 0.06 & 0.10 & 0.09 \\
\hline 7. & 2.197 & Ethyl vinyl ketone & 0.32 & 0.09 & 0.15 & - & - & - \\
\hline 8. & 2.325 & Pentanal & 0.51 & 0.40 & 2.05 & 0.45 & 1.27 & 0.76 \\
\hline 9. & 2.357 & Furan, 2-ethyl- & 3.38 & 0.63 & 0.13 & - & - & 0.32 \\
\hline 10. & 3.181 & (E)-2-Pentenal & 0.30 & 0.12 & 0.30 & 0.25 & 0.73 & 0.62 \\
\hline 11. & 4.101 & n-Hexanal & 2.52 & 2.53 & 2.93 & 1.97 & 0.77 & 3.88 \\
\hline 12. & 5.514 & (E)-2-Hexenal & 8.23 & 9.21 & 8.85 & 0.78 & 1.40 & 1.85 \\
\hline 13. & 5.589 & cis-3-Hexene-1-ol & 1.71 & 0.34 & 1.13 & 0.11 & 0.13 & 0.35 \\
\hline 14. & 6.028 & n-Hexanol & 0.25 & 0.16 & 0.20 & 0.15 & 0.11 & 0.09 \\
\hline 15. & 7.025 & Heptanal & 1.62 & 0.91 & 0.82 & 0.15 & 0.39 & 0.24 \\
\hline 16. & 7.837 & $\alpha$-Thujene & 0.20 & 0.17 & 0.20 & 0.18 & 1.01 & 1.73 \\
\hline 17. & 8.069 & $\alpha$-Pinene & 1.37 & 0.56 & 0.86 & 14.90 & 15.59 & 14.63 \\
\hline 18. & 8.944 & 2-Heptenal & 0.31 & 0.34 & 0.10 & 0.67 & 0.15 & 0.79 \\
\hline 19. & 9.043 & Benzaldehyde & 1.31 & 0.74 & 1.03 & 0.50 & 0.17 & 0.40 \\
\hline 20. & 9.647 & 2-.ק.-Pinene & 0.76 & 0.30 & 0.49 & 0.60 & 0.59 & 0.50 \\
\hline 21. & 9.909 & Vinyl amyl carbinol & 2.00 & 1.09 & 0.51 & 0.50 & 0.36 & 0.35 \\
\hline 22. & 10.023 & 6-Methyl-5-hepten-2-one & 1.18 & 0.32 & 0.49 & - & - & - \\
\hline 23. & 10.202 & Myrcene & 0.65 & 0.20 & 0.26 & 1.86 & 1.20 & 1.07 \\
\hline 24. & 10.208 & 2-Pentylfuran & 0.50 & 0.57 & 0.29 & - & - & - \\
\hline 25. & 10.527 & 2-[(2E)-2-Pentenyl]furan & 0.31 & 0.41 & 0.30 & - & - & - \\
\hline 26. & 10.705 & Octanal & 0.47 & 0.40 & 0.21 & 0.41 & 0.18 & 0.78 \\
\hline 27. & 10744 & $\alpha$-Phellandrene & - & - & - & 0.56 & 0.28 & 0.18 \\
\hline 28. & 10.968 & 2,4-Heptadienal & 0.42 & 0.09 & 0.22 & - & - & - \\
\hline 29. & 11.458 & Cymene & - & - & - & 0.33 & 0.34 & 0.60 \\
\hline 30. & 11.649 & Limonene & 1.89 & 1.00 & 1.28 & 2.70 & 2.36 & 3.65 \\
\hline 31. & 12.005 & 3-Octen-2-one & 0.09 & 0.10 & 0.20 & 6.79 & 6.97 & 5.72 \\
\hline 32. & 12.134 & Benzeneacetaldehyde & 0.57 & 0.38 & 0.55 & - & - & - \\
\hline 33. & 12,370 & Trans-.ק.-Ocimene & - & - & - & 0.68 & 0.42 & 0.11 \\
\hline 34. & 12.763 & (E)-2-Octenal & 0.20 & 0.28 & 0.55 & 0.45 & 0.32 & 0.58 \\
\hline 35. & 14.417 & Linalool & 0.97 & 0.57 & 0.62 & - & - & - \\
\hline 36. & 14.590 & n-Nonanal & 0.65 & 0.98 & 0.52 & 0.70 & 0.29 & 1.24 \\
\hline 37. & 15.501 & (4E,6Z)-Alloocimene & - & - & - & 0.73 & 0.82 & 0.23 \\
\hline 38. & 17.824 & Methyl salicylate & 0.30 & 0.28 & 0.19 & - & - & - \\
\hline 39. & 18.452 & Decanal & 0.70 & 0.41 & 0.16 & 1.02 & 0.38 & 0.93 \\
\hline 40. & 22.975 & Cyclohexane & - & - & - & 0.22 & 0.23 & 0.17 \\
\hline 41. & 23.086 & $\delta$-Elemene & - & - & - & 0.41 & 0.43 & 0.21 \\
\hline 42. & 23.506 & .. -Cubebene & 0.23 & 0.22 & 0.16 & 5.16 & 5.13 & 5.38 \\
\hline 43. & 24.264 & Ylangene & - & - & - & 0.45 & 0.70 & 0.34 \\
\hline 44. & 24.479 & .a.-Copaene & 0.66 & 0.70 & 0.55 & 1.93 & 1.77 & 1.21 \\
\hline 45. & 24.744 & .ß.-Bourbonene & 0.39 & 0.23 & 0.15 & 0.25 & 1.97 & 0.24 \\
\hline 46. & 24.949 & .ß.-Elemene & - & - & - & 0.23 & 0.68 & 0.15 \\
\hline 47. & 25.546 & .a.-Gurjunene & - & - & - & 0.34 & 0.48 & 0.36 \\
\hline 48. & 26.076 & $\beta$-Caryophyllene & 46.65 & 60.23 & 56.01 & 1.07 & 1.01 & 1.26 \\
\hline 49. & 26.238 & 10,10-dimethyl-2,6-bis(methylene)- & 0.43 & 0.44 & 0.25 & 0.30 & 0.50 & 0.70 \\
\hline 50. & 26.565 & $\gamma$. -Muurolene & - & - & - & 1.56 & 1.84 & 1.76 \\
\hline 51. & 26.570 & (+)-Aromadendrene & 0.26 & 0.17 & 0.51 & - & - & - \\
\hline 52. & 27.108 & (E)- $\beta$-Farnesene & - & - & - & 16.47 & 17.69 & 15.69 \\
\hline 53. & 27.124 & . $\alpha$. -Humulene & 1.50 & 1.25 & 1.55 & - & - & - \\
\hline 54. & 27.359 & Epi-bicyclosesquiphellandrene & - & - & - & 0.30 & 0.52 & 0.50 \\
\hline 55. & 27.730 & Cadina-1(6),4-diene & - & - & - & 0.46 & 0.36 & 0.94 \\
\hline 56. & 27.971 & Germacrene-D & 8.74 & 9.76 & 9.29 & 17.78 & 18.92 & 16.16 \\
\hline 57. & 28.305 & a.-Copaene & 0.40 & 0.23 & 0.29 & 2.50 & 1.57 & 2.76 \\
\hline 58. & 28.438 & Bicyclogermacrene & 1.09 & 0.62 & 0.74 & 3.46 & 3.04 & 3.17 \\
\hline 59. & 28.548 & $\alpha$-Muurolene & 0.21 & 0.17 & 0.50 & 0.25 & 0.62 & 0.20 \\
\hline 60. & 28.998 & . $\gamma$-Cadinene & 0.39 & 0.21 & 0.50 & 2.80 & 0.41 & 0.71 \\
\hline 61. & 29.176 & $\delta$-Cadinene & 0.73 & 0.40 & 0.54 & 3.83 & 4.27 & 3.62 \\
\hline 62. & 30.409 & Germacrene B & - & - & - & 1.38 & 0.38 & 1.08 \\
\hline 63. & 30.954 & Spathulenol & - & - & - & 0.21 & 0.25 & 0.28 \\
\hline 64. & 31.105 & Caryophyllene oxide & 0.33 & 0.30 & 0.52 & - & - & - \\
\hline
\end{tabular}




\section{Discussion and Conclusions}

SPME analysis revealed that Phlomis rigida Labill. and P. monocephala P.H.Davis had 49 different volatile components. Main components of Phlomis rigida were (E)-2Hexenal (9.21\%), $\beta$-Caryophyllene (60.23\%) and Germacrene D (9.76\%). Demirci et al. (2006) found through GC-MS analysis that the main components of Phlomis rigida Labill. were $\beta$-Caryophyllene $(31.2 \%$ - 38.7\%) and $\beta$-selinene $(13.1 \%-15.1 \%)$. $\beta$ Caryophyllene was found to be the dominant component in that study. This finding is consistent with our result. Contrary to the abovementioned study, (E)-2-Hexenal and Germacrene D were also identified as dominant components in our study.

$\alpha$-Pinene $(15.59 \%),(\mathrm{E})-\beta$-Farnesene $(17.69 \%)$ and Germacrene D (18.92\%) were found to be the main components of Phlomis monocephala. In a study conducted by Demirci et al. (2009), they aimed at exploring the antimicrobial effects and phytochemical profile of Phlomis lunariifolia Sm., Phlomis amanica Vierh., Phlomis monocephala P.H. Davis, Phlomis sieheana Rech. fil., Phlomis armeniaca Willd. species in Turkey. They applied GC and MS for the analysis of the volatile oils that they derived through hydrodistillation. They identified 143 components in the volatile oils of Phlomis amanica Vierh. and Phlomis monocephala P.H.Davis. They found that 8(14), 15-Isopimaradien-11 $\alpha$-ol (1) were the main components in the volatile oils of Phlomis monocephala P.H.Davis. This finding is different from our result. Contrary to that study, Germacrene D, (E)- $\beta$-Farnesene and $\alpha$-Pinene were identified as the dominant components in our study.

In conclusion, the volatile components $\beta$-Caryophyllene, (E)-2-Hexenal, Germacrene $\mathrm{D},(\mathrm{E})-\beta$-Farnesene and $\alpha$-Pinene obtained in this study may be considered as potential sources and materials for the pharmacology and cosmetic industry thanks to their antimicrobial activities. It was found that reaping $P$. rigida and $P$. monocephala species, which were collected from the field in the form of leaves and flowers, during the flowering period was important with respect to the yield of volatile components. These findings are considered to help preventing the haphazard collection of plants by traders and local people and economic losses that may arise due to misinformation and raise awareness for the collection of the plants. Although Phlomis taxa are used in many areas, there are limited numbers of studies conducted on Phlomis taxa in Turkey. There is a need for further studies in this field.

\section{REFERENCES}

[1] Baydar, H. (2009): Tibbi ve Aromatik Bitkileri Bilimi ve Teknolojisi. - Isparta: Süleyman Demirel Üniversitesi Ziraat Fakültesi, 348 p.

[2] Baytop, T. (1997): Türkçe Bitki Adları Sözlüğü. - TDK. Yayınları.

[3] Davis, P. H. (1982): Flora of Turkey and The East Aegaen Islands, 7. - Edinburg: Edinburg University Press.

[4] Davis, P. H. (1988): Flora of Turkey and The East Aegaen Islands, 10. - Edinburg: Edinburg University Press.

[5] Demirci, B., Baser, K. H. C., Dadandi, M. Y. (2006): Composition of The Essential Oils of Phlomis rigida Labill. and P. samia L. - Journal of Essential Oil Research 18: 328331.

[6] Demirci, F., Guven, K., Demirci, B., Dadandi, M. Y., Baser, K. H. C. (2008): Antibacterial activity of two Phlomis essential oils against food pathogens. - Food Control 19: 1159-1164. 
[7] Durmuşkahya, C. (2005): Aşağı Gediz Havzası Vejetasyon Ekolojisi. - Celal Bayar Üniversitesi, Fen Bilimleri Enstitüsü, Biyoloji Anabilim Dalı, Doktora Tezi, 169 p.

[8] Guner, A. (2012): Türkiye Bitkileri Listesi, Damarlı Bitkiler. - Istanbul: Nezahat Gökyiğit Botanik Bahçesi Yayınları.

[9] Harput, Ü. Ş., Çalış İ., Saraçoğlu, İ., Dönmez, A. A., Nagatsu, A. (2006): Secondary Metabolites from Phlomis syriaca and Their Antioxidant Activities. - Turkish Journal of Biology 30: 383-390.

[10] Kamel, M. S., Mohamed, K. M., Hassanean, H. A., Ohtani, K., Kasai, R., Yamasaki, K. (2002): Iridoid and megastigmane glycosides from Phlomis aurea. - Phytochemistry 55: 353-357.

[11] Kubecka, K. H. (1973): Separation of essential oils and similar complex mixtures by means of modified dry-column chromatography. - Chromatographia 6: 106-108.

[12] Morgaris, N., Koedam, A., Vokou, D. (1982): Aromatic Plants. - Martinius Njhoff Publisher Vol:7: 265-269, London.

[13] Tan, A. (1992): Türkiye'de Bitkisel Çeşitlilik ve Bitki Genetik Kaynakları. - Anadolu Journal of AARI 2: 50-64.

[14] Tanker, M., Tanker, N. (1990): Farmakognozi. Cilt.2. - Ankara: Ankara Üniversitesi Eczacılık Fakültesi Yayınları.

[15] Watson, L., Dallwitz, M. T. (1978): The Families of Flowering Plants. - London: Oxford University Press.

[16] Weiss, E. A. (1997): Essential Oil Crops. - The Journal of Agricultural Science 129: 121123.

[17] Zhang, Y., Wang, Z. Z. (2008): Comparative analysis of essential oil components of three Phlomis species in Qinling Mountains of China. - Journal of Pharmaceutical and Biomedical Analysis 47(1): 213-217. 